\title{
An Investigation into Writing Strategies and Writing Proficiency of University Students
}

\author{
Saeid Raoofi \\ Farhangian University (Shahid Modares Campus), Sanandaj, Iran \\ Massoud Binandeh \\ Farhangian University (Shahid Modares Campus), Sanandaj, Iran \\ Saifullah Rahmani \\ Farhangian University (Shahid Modares Campus), Sanandaj, Iran
}

\begin{abstract}
This paper reports on an investigation into the relationship between writing strategy use and $\mathbf{L 2}$ writing proficiency. Although research into language learning strategies is extensive, only a few studies have addressed L2 writing strategies of university students. 312 undergraduate students learning English as a second language took a writing proficiency test and completed a writing strategy questionnaire. The results of the study showed that the participants generally had a relatively high level of ESL writing strategy use. It was also found that Effort regulation strategy and metacognitive strategy were reported as the first and second most frequently used writing strategies respectively, while social strategy was reported as the least frequently used category. The results also showed that students with high writing abilities reported a significantly higher level of writing strategy use compared with those who had intermediate or low writing proficiency. It was found that students with higher writing ability reported using significantly more metacognitive, cognitive, affective and effort regulation strategies than those with lower writing proficiency. The discussion of the results, implications for language classroom and writing instruction are articulated. Limitations of the study and suggestions for future research are also presented.
\end{abstract}

Index Terms - writing strategies, writing proficiency, second language learning, ESL writing, university students as writers

\section{INTRODUCTION}

Language learning strategies have been shown to be highly influential in the success of language learning. The language strategies are conscious techniques that individuals use to solve problems in their language learning process (Brown 2000). There has been a rapidly increasing body of research on language learning strategies since the mid-1970s (Hong-Nam \& Leavell, 2006; Ma \& Oxford, 2014; O'Malley et al., 1985; Oxford, 1990; Rubin, 1975). Although there is a rapidly growing body of research focusing on the various aspects of language learning strategies, there have been controversies among the researchers about the definition of language learning strategies. Generally, learning strategies have not been clearly defined and there are many definitions for the language learning strategies in the SLA literature.

Various taxonomies of language learning strategies have been proposed by SLA scholars and researchers (Cohen, 1998; O’Malley \& Chamot, 1990; Oxford 1990; Wenden \& Rubin, 1987). Some of these taxonomies such as Oxford's (1990) strategy system and O'Malley and Chamot's (1990) strategy taxonomy have received much attention in L2 learning. Oxford's (1990) strategy taxonomy which encompasses six categories includes cognitive strategies, metacognitive, memory, compensatory, social and affective strategies, while O’Malley and Chamot (1990) have categorized them into cognitive, metacognitive and socio-affective categories.

Many research attempts in the area of L2 learning strategies have mainly focused on successful learners. Researchers believe that good language learners use a wide variety of strategies and tactics to do their learning tasks effectively in a given situation. Dörnyei (2005) stated that learners who are good at language learning tend to have a bigger repertoire of strategies than less proficient learners, and they employ the strategies more effectively. Successful language learners use various types of strategies for different language tasks; they choose appropriate strategies for a task based on task specifications (Chamot \& El-Dinary, 1999). In identifying strategies, efforts have also been made in research to be skillbased such as that of focusing on writing.

The development of writing is needed for university students as it is a very essential skill for their academic development. Writing is considered as an important ability for production and dissemination of knowledge within any disciplinary discourse. It is valid to say that the assessment of the students' academic achievements in academic contexts relies largely on their abilities to convey their knowledge and ideas. It helps students to do key assignments, enhance their critical thinking capabilities and develop their cognitive performance and functioning (Graham \& Perin, 2007). Within educational contexts, the ability to write in English is very fundamental and instrumental for university 
students to function successfully in their academic areas. In academic settings, writing in English enables students to share their research findings with global readership, and it allows the student to place their thoughts and research in an international outlet.

Writing skills enable us to communicate with people beyond the limits of time and distance. It is an essential skill for students in the current internet-driven epoch. It is a valid mode for the transmission of culture, knowledge and ideas from one generation to another, and hence it directly deals with preserving and developing the sociocultural, educational and anthropological aspects of human life. In other words, writing is not only considered as criteria of getting knowledge, but it is also an important means for disseminating and producing knowledge in any educational and cultural system. Canagarajah (2002) ascribes the importance of writing to the five salient features of writing. First, writing both reflects and creates reality; second, writing is a social interactional activity between the writer and the reader within a specific space and time. Third, writing is created from the negotiation between writer and available resources in a context. Fourth, writing provides an opportunity for writers to present ideological beliefs, to express self and to give value to entities through the text. Fifth, writing is a historical dynamic process where the ideas, struggles, conflicts and concepts of the text are open to the readers and writers' comments and stance.

Writing is one of the essential skills that university students need to master in order to achieve their academic goals and get better job prospects. Indeed, good writing ability often indicates an ability of the individuals to attain professional development in their academic areas. In Malaysia, writing in English has been highlighted in national exams and assessments such as that of Lower Secondary School Certificate, Secondary Leaving School Certificate and Malaysian University English Test (MUET). In each of these examinations, there is a section assessing students' writing ability in English. English as a second language is a taught subject in Malaysia and is compulsory for students at all levels in schools. In Malaysia, university students have positive attitudes towards writing in English (Ansarimoghaddam \& Tan, 2014). In spite of considerable attention given to English particularly writing skill in Malaysia, still every year, a great number of Malaysian undergraduates are obliged to attend writing classes due to their low scores in English proficiency and writing. Therefore, the specific problems that Malaysian students face when writing in English within ESL contexts need to be further investigated and documented, and it is essential to understand what factors account for the difficulties students encounter in their L2 writing activities.

Writing is a complex and multifactorial phenomenon; it is more challenging for learners who write in a language other than their first language. Weigle (2005) asserted that L1 writers have automatic and quick access to grammatical and lexical repertoires while second language writers especially those with a low level of language proficiency need to consciously focus on these processes since the strategies and language knowledge are not easily available to them when they attempt to write in their second language. Rao (2007) stated that, writing in L2 is a difficult task for the students because the writing task requires different linguistic and cognitive strategies which students are not certain about.

Given the multifaceted nature of L2 writing, and the significant role of writing proficiency in academic settings, it is important to understand to what extent ESL university students use writing strategies in creating their L2 writing and, how their writing proficiency is related to their writing strategy use. Understanding and identifying L2 writing strategies and techniques is very essential for language instructors to improve the writing curriculum and also helps them to plan their writing lessons appropriately and effectively. Since individuals differ in the ways they approach the processes to perform a task, It is worth examining how students' planning and monitoring processes in producing ideas, and the ways they orchestrate their efforts to create L 2 writing are influenced by their writing ability.

\section{WRITING STRATEGIES}

It is believed that writing strategies play a key role in the development of L2 writing. The past couple of decades have witnessed a substantial body of L2 writing research targeting writing strategies (Roca de Larios et al. 2008; Sasaki, 2002, 2007 Victori 1999; Whalen \& Menard 1995; Wong, 2005). Research investigating the relationship between L2 Writing strategies and writing ability indicates that students' with high writing ability use more writing strategies than those who have low writing ability (Sasaki, 2002; Victori, 1999), and hence writing proficiency can explain some variation in the use of writing strategies. Research in the field of second language writing has also addressed the use of L2 writing strategies in relation to goal orientation (He, 2005), writing performance (Nguyen and Gu 2013), and learning context (Leki, 1995, Sasaki, 2007; Wong, 2005).

L2 writing research also examined the link between L1 and L2 writing strategies L1 writing strategies (Alhaisoni, 2012; Whalen \& Menard 1995). Research indicates that there is a link between the L1 and L2 strategies, though there are some inclusive research findings. Generally, it can be concluded from previous research that L2 learners transfer some of the writing techniques and strategies from their witting in their mother tongue to their writing in a second language. Writing strategies are thought to be learned in first language, and then transferred to L2 writing. Therefore, learners who have a wealth of experiences in L1 writing are more likely to be more successful in L2 writing endeavors. It is reasonable to assume that L1 writing experiences, to some extent, shape the way learners approach the L2 writing tasks.

Despite the rapidly growing research on various aspects of L2 writing, little research has focused on documenting the nature of the writing strategies used by second language learners. Furthermore, very few studies have examined the use of writing strategies by university students within second language learning contexts. Most of the research studies 
available have addressed generic language learning strategies, rather than L2 writing strategies. Considering the lack of research on the university students' writing strategies within Malaysian ESL context, this study aims to address the following research questions: What are the ESL writing strategies of Malaysian undergraduate students? Are there any significant differences between students with different levels of English writing proficiency in the use of writing strategies?

\section{Methodology}

\section{A. Participants}

In total, 314 university students (all Malaysian nationals) at a national university in Malaysia participated in this study. 89 were male and 225 were female. They came from three L1 backgrounds, (Malay, Chinese and Tamil), the majority had Malay as their L1, and the remainder had either Chinese or Tamil as their L1. They were all first-year and second-year undergraduate students, and ranged in age from 19 to 24 years. The participanthals represented a wide range of fields of study offered by the university. The participants in this study completed a questionnaire and two writing tasks.

\section{B. Instrument}

1. Writing Strategy Scale. A 26-item scale was designed to assess L2 learners' writing strategy use. The scale comprised of five writing strategy categories: metacognitive, cognitive, social, affective and effort regulation strategies. The items for the scale were adapted from four sources: He's (2005) writing strategy questionnaire, a writing strategy scale by Petrić and Czárl (2003), Oxford's (1990) Strategy Inventory for Language Learning, and Pintrich et al.’s (1993) Motivated Strategies for Learning Questionnaire (MSLQ). Modifications were made to the strategy scale items, specifically items from Oxford's (1990) and Pintrich et al.'s (1993) scales in order to prompt participants to consider L2 writing strategies when responding rather than be constrained by general language learning strategies or general learning strategies. Participants were asked to rate the extent to which the statements in the scale corresponded with their actual use of writing strategies, using a scale ranging from 1 (Never true of me) to 5 (Always true of me). The internal consistency reliability of the scale calculated using Cronbach's alpha, was high, $\alpha=0.91$. The questionnaire was presented to the participants in both English and Malay languages since the bilingual version of the scale are required for L2 respondents especially for those with low proficiency in the second language.

2. Writing Proficiency Test. The study included two writing tasks from the Writing Section of Malaysian University English Test (MUET), developed to measure writing skill for students entering tertiary education in Malaysian public universities. The writing test (the two tasks) was delivered in the classroom by the researcher. The first task required the test-takers to write a descriptive report using data given in a table and a graph, while the second task required them to write an argumentative essay. The total writing score was 100, of which 40 marks went to task 1 , and the other 60 marks were allotted to task2. The students were classified into three writing proficiency groups (low, middle and high) on the basis of the score they got on the writing test.

\section{Data Collection and Analysis}

The data was collected during the regular class time with the cooperation of writing instructors in charge of the writing class. After explaining the purpose of the study to the students, they were told that the participation in this study was voluntary and their answers would be kept confidential. They were also told that participation in the study involved taking a writing proficiency test and completing a questionnaire. No time limit was set for the completion of the writing strategy questionnaire, but for the writing test, the students were advised to spend 40 minutes on writing task 1 , and 50 minutes on writing task 2 .

The data collected from the writing strategy scale and writing proficiency test were analyzed using Statistical Package for Social Sciences (SPSS, version 22). For the first research question, descriptive statistics for writing test scores, writing strategy categories and total writing strategy use were calculated. For the second research question, Analysis of Variance (ANOVA) was used to investigate the differences in the use of writing strategies among the three writing ability groups (low, middle and high).

\section{RESULTS}

Means and standard deviations of the entire writing strategy use, scores for the five categories of writing strategies, and individual strategies were calculated for the whole sample. Oxford (1990) classified the mean scores of the strategy use into three levels as low (ranging from 1.0 to 2.4) medium (ranging from 2.4 to 3.5 ) and high (ranging from 3.5 to 5 ). The participants reported almost a high level of writing strategy use as the overall mean of writing strategy usage was 3.72. As can be seen in Table 1, all of the categories had mean score above 3.5, indicating that all strategy categories were frequently employed by the participants. Among the five categories, effort regulation strategy $(\mathrm{M}=3.97, \mathrm{SD}=.42)$ and metacognitive strategy $(\mathrm{M}=3.73, \mathrm{SD}=.41)$ were reported as the first and second most frequently used strategies respectively while social strategy was reported as the least frequently used category $(\mathrm{M}=3.58, \mathrm{SD}=.57)$. 
TABLE 1

\begin{tabular}{lllll}
\multicolumn{5}{c}{ MEANS AND RANKING OF FIVE WRITING STRATEGY CATEGORIES } \\
\hline Writing strategies & N & Mean & SD & Ranking \\
\hline Effort regulation & 314 & 3.97 & .42 & $1^{\text {st }}$ \\
Affective & 314 & 3.63 & .48 & $4^{\text {th }}$ \\
Social & 314 & 3.58 & .57 & $5^{\text {th }}$ \\
Cognitive & 314 & 3.64 & .40 & $3^{\text {rd }}$ \\
Metacognitive & 314 & 3.73 & .41 & $2^{\text {nd }}$ \\
\hline
\end{tabular}

Another analysis of data with regard to individual writing strategies found that a metacognitive strategy "I revise my writing to make sure that it includes everything I want to discuss in my writing" $(\mathrm{M}=4.02)$ and effort regulation strategy "Even if the writing activities are difficult, I don't give up but try to engage in them" $(\mathrm{M}=4.02)$ were the most used strategies. Social and affective strategies were the least used among the participants. Among the strategies, the least used strategies were "After revising and editing my essay thoroughly, I ask a friend or my classmate to read and comment on it" $(\mathrm{M}=3.33)$ and "I try to write an essay in class with confidence and ease" $(\mathrm{M}=3.38)$. It was also found that only five items had a mean score below 3.5; it indicates that Malaysian university students use different techniques and strategies in their writing endeavors as they consider writing as a very essential skill for their studies.

A series of ANOVA tests were conducted to examine the differences in the use of writing strategies among three writing proficiency groups .As mentioned earlier, writing ability groups (low, middle and high) were determined based on their scores on two writing tests. Assumptions of ANOVA (e.g., homogeneity of variance, normality) were checked before performing ANOVA. The results of the first ANOVA showed that that the proficiency groups differed in their overall use of strategies $F(2,311)=13.01, p=.00, \eta^{2}$ (eta-squared) $=.080$. Follow-up Scheffé analyses showed that high proficiency group reported significantly more writing strategies than the middle group who in turn used significantly more writing strategies than the low group.

With regard to each category of writing strategy, the results showed that there were significant differences among the groups in their use of metacognitive strategies, $\mathrm{F}(2,311)=15.61, p=.00, \eta^{2}$ (eta-squared) $=.094$. Further analysis using post hoc Scheffé tests revealed that there were significant differences between the high and intermediate proficiency groups $(p=.01)$, between the high and low proficiency groups, $(p=.00)$, and between intermediate and low proficiency groups $(p=.00)$.

The results also showed significant differences among writing ability groups in their cognitive writing strategies. F (2, $311)=11.30, p=.00, \eta^{2}$ (eta-squared) $=.070$. Post hoc comparison analyses indicated that participants with high writing proficiency reported significantly higher use of metacognitive writing strategies than those with intermediate writing ability $(p=.00)$ and those with low writing ability $(p=.00)$. However, no significant difference was found between low and intermediate groups $(p=.42)$. Summary of the results for the five writing strategy categories among the three writing proficiency levels are given in Table 2.

It was also found that the proficiency groups differed significantly in their effort regulation strategies. F $(2,311)=$ $10.42, p=.000, \eta 2=.065$. Follow-up Scheffé test revealed that the high writing ability group reported making a significantly higher use of effort regulation strategies than low writing ability group $(p=.00)$. There was also a significant difference between low and middle writing ability group $(p=.00)$ while there was no significant difference between middle and high ability writing groups in their effort regulation strategies $(p=.27)$.

TABLE 2

SUMMARY OF DIFFERENCES IN THE USE OF WRITING STRATEGIES BY WRITING PROFICIENCY

\begin{tabular}{|c|c|c|c|c|c|c|c|c|}
\hline \multirow[t]{2}{*}{ Writing strategy categories } & \multicolumn{2}{|c|}{$\begin{array}{l}\text { Low } \\
(n=76)\end{array}$} & \multicolumn{2}{|c|}{$\begin{array}{l}\text { Middle } \\
(\mathrm{n}=178)\end{array}$} & \multicolumn{2}{|c|}{$\begin{array}{l}\text { High } \\
(n=60)\end{array}$} & \multirow[t]{2}{*}{$\mathbf{F}$} & \multirow[t]{2}{*}{$p$ Value } \\
\hline & Mean & SD & Mean & SD & Mean & SD & & \\
\hline Social & 3.50 & .57 & 3.63 & .55 & 3.53 & .60 & 1.09 & .33 \\
\hline Metacognitive & 3.49 & .43 & 3.75 & .36 & 3.97 & .35 & 15.61 & .00 \\
\hline Cognitive & 3.51 & .39 & 3.60 & .36 & 3.91 & .34 & 11.30 & .00 \\
\hline Affective & 3.43 & .55 & 3.65 & .44 & 3.83 & .40 & 8.08 & .00 \\
\hline Effort regulation & 3.75 & .45 & 4.1 & .36 & 4.13 & .34 & 10.42 & .00 \\
\hline
\end{tabular}

There were also statistically significant differences in affective strategies among the three writing proficiency groups (. F $(2,311)=8.08, p=.000, \eta 2=.051$. Post hoc Scheffé test indicated that highly proficient writers did not differ significantly from moderately proficient writers $(p=.120)$ while highly proficient writers differed significantly those with low writing proficiency in affective strategies. The difference between low and middle proficiency groups was also significant $(p=.023)$. Unlike other categories of writing strategies, the category of social writing strategies was not significantly different among the three writing proficiency groups, $\mathrm{F}(2,311)=1.09, p=.33, \eta 2=.007$.

\section{DisCUSSION AND CONCLUSION}

The participants generally reported a relatively high level of writing strategy use as the overall mean of writing strategy usage was 3.72. Indeed, ESL Malaysian students reported using writing strategies at a moderate to high level. One possible explanation for the slightly high usage of writing strategies is that these students are ESL university students in a writing course who may have explicitly been taught some techniques and strategies about ESL writing. In 
addition to the effect of the writing course, the Malaysian ESL university context may have affected their strategy use. Students in ESL university contexts understand the importance of English for their academic achievements as they are required to write their assignments and reports in English. Thus, it can be assumed that the students in such contexts are required to develop their writing ability, and consequently they are likely to allocate considerable attention to the different ways and techniques to expand their writing skill.

It is worth noting that the strategies used by learners in their general language learning in which writing is only a part of the whole language may be different from those they employ specifically in their L2 writing endeavors. Regardless of this difference, this result is similar to that of Hong-Nam and Leavell's (2006) study which reported a high overall strategy use among ESL university students. Nevertheless, the overall strategy use reported in several studies focusing on language learning strategy use (Lai, 2009; Park, 1997) was moderate or low. This finding seems to reflect the fact that students in SL contexts have access to authentic L2 input and they have more interaction opportunities than those in FL contexts. This explanation supports Wharton's (2000) argument that exposure to authentic input and interaction opportunities affect the strategy use.

Among the five categories, effort regulation strategy $(\mathrm{M}=3.97, \mathrm{SD}=.42)$ and metacognitive strategy $(\mathrm{M}=3.73, \mathrm{SD}$ $=.41)$ were reported as the first and second most frequently used strategies respectively while social strategy was reported as the least frequently used category $(\mathrm{M}=3.58, \mathrm{SD}=.57)$. ESL students in the writing course seem to know the need to regulate and manage their writing processes and showed they had control over planning and organizing, and focusing their own writing. The learning environment of the writing course may be an important contributor to the high usage of metacognitive and effort-regulation strategies. Writing course students were learning to advance their academic writing. They appeared to know the need of writing as an essential skill for being successful in any academic area. The threat of getting a low grade, or the threat of not getting success in their study was likely to be an important motivator for taking self-regulated learning.

Although social writing strategy was less employed by the participants compared to the other categories, it was highly used by the students. The means score for the writing strategy was 3.58 which shows that the students reported using social writing strategies at a high level according to the Oxford's (1990) guidelines for the use of language learning strategies. Regardless of the differences between ESL writing strategies and general ESL language learning strategies, this result corroborates the findings of Hong-Nam and Leavell's (2006) investigation of ESL Asian university students who reported high use of metacognitive, social and cognitive strategies at a high level (above 3.4 out of 5).

The results also showed that that the proficiency groups differed in their overall use of strategies. That is, the higher the proficiency level, the greater was the strategy use. This finding was in line with that of previous studies (e.g., Bruen, 2001; Park,1997; Lai, 2009; Wharton, 2000) that indicated that L2 proficiency is significantly associated with strategy use. Thus, the results of this study support the linear relationship between strategy use and L2 proficiency. The results contradicts the findings of Hong-Nam and Leavell, (2006) and Philips's (1991) studies which showed that the relationship between L2 proficiency and strategy use is curvilinear rather than linear. These researchers argued that learners in intermediate proficiency group use more strategies than those in low and high proficiency groups.

With regard to each category of writing strategies, the results showed that there were significant differences among the groups in their use of metacognitive strategies, $\mathrm{F}(2,301)=15.61, p=.00, \eta 2$ (eta-squared) $=.094$. From the results, it can be assumed that the highly successful student writers employ more monitoring and planning strategies than moderately successful and unsuccessful ones, showing that the metacognitive strategy use is an important contributor to the development of L2 writing skill. This finding is in agreement with those from previous studies (Bruen, 2001; Lai, 2009; Green \& Oxford, 1995; Peacock \& Ho, 2003; Victori, 1999) which demonstrated that higher level of language proficiency is strongly related to higher usage of metacognitive strategies. The results suggest that the strategies which help students to control and regulate their own cognition may be essential for developing L2 writing skill. Though, metacognitive strategies are positively linked with L2 proficiency, some caution is required for the interpretation of results because the direction for the causal relation between the language learning strategies and language proficiency is not clear (Lai, 2009; Rees-Miller, 1993). Still further investigation is needed to determine whether strategies cause improvement in language proficiency or vice versa.

The results also showed significant differences among writing ability groups in their cognitive writing strategies. F (2, $301)=11.30, p=.00, \eta 2$ (eta-squared) $=.070$. The results of this study suggest that effective student writers are more capable of using cognitive strategies for producing written language and hence it can be assumed that this type of strategy category seem to be very essential for successful L2 writing production. This finding seems to be similar to, and confirms that of previous studies (Bruen, 2001; Lai, 2009; Liu, 2008; Peacock \& Ho, 2003).

It was also found that the proficiency groups differed significantly in their effort regulation strategies, F $(2,301)=$ $10.42, p=.000, \eta 2=.065$. However, follow-up Scheffé test revealed that there was not a significant difference between middle and high ability writing groups in their effort regulation strategies $(p=.27)$. Unfortunately no study in the area of SLA has focused on the role of effort regulation strategies in language learning. This study found that in addition to cognitive and metacognitive strategies, effort regulation strategies appear to be among the key strategies employed by successful L2 learners. In line with previous studies, this study found that the students who reported being able to regulate and maintain their effort in face of distracting factors and boring tasks are the more successful students. 
The results obtained from the present study is in harmony with the previous research in the fields of education and psychology (Bidjerano \& Dai, 2007; Pintrich, et al., 1993; Van Nuland, et al., 2010; ) which shows that effort regulation strategies are closely related to successful performance. Van Nuland, et al., (2010) and Komarraju and Nadler (2013) demonstrated that successful learners use more effort regulation strategies in their learning.

There were also statistically significant differences in affective strategies among the three writing proficiency groups $(\mathrm{F}(2,301)=8.08, p=.000, \eta 2=.051$. However Post hoc Scheffé test indicated that highly proficient writers did not differ significantly from moderately proficient writers $(p=.120)$. Combined with findings of previous research (Khaldieh, 2000; Lai, 2009; Liu, 2008;) the present finding reveal that learners with high language proficiency use more affective strategies than those with low proficiency. They use these strategies to reduce their anxiety in order to increase their learning and performance. The causes of high use of affective strategy by students in high proficiency group may be attributed to their self-efficacy. As Bandura (1997) claims that successful learners because of their mastery experiences usually have high self-efficacy. Bandura (1997) also asserted that academic anxiety is largely determined by self-efficacy beliefs. Thus, it can be assumed that highly successful student writers have lower level of L2 writing anxiety and also can better regulate and control their emotions compared with less successful student writers.

Unlike other categories of writing strategies, the category of social writing strategies was not significantly different among the three writing proficiency groups, $\mathrm{F}(2,301)=1.09, p=.33, \eta 2=.007$. In this study, higher writing proficiency levels were not associated with higher social strategy use. This finding stands in contrast with that of previous studies (e.g., Salahshour, et al., 2013; Lai, 2009) in that L2 proficiency significantly affected social strategy use. This result may be explained with reference to several factors. First, within university contexts, majority of students, regardless of their language proficiency level, probably need help and guidance for their academic writing because it involves subject knowledge as well. Second, personality traits such as extroversion appear to be an important factor in determining the use of the social strategies (Liyanage \& Bartlett, 2013). Thus, it can be assumed that there are factors other than proficiency which affect the use of social strategies. It seems reasonable that social strategies are employed more by extrovert students than by introvert students. Third, the three proficiency groups reported using the social strategies at the similar level, indicating that a culturally-driven approach to learning within this particular multi-ethnic Asian context may be in operation.

The findings of the study revealed that Malaysian university students use writing strategies at a relatively high level. The participants reported using all categories of writing strategies, though they had a slightly higher tendency toward the use of effort regulation and metacognitive strategies than affective, social and cognitive ones. The results of this study also showed that writing proficiency would explain some variation in the use of writing strategies. The use of all writing strategy categories, except social strategy, across the three writing proficiency groups (highly skilled, moderately skilled and less-skilled student writers) differed significantly. However, there are several limitations that should be acknowledged and considered in the interpretation of these findings. First, the study used only self-reported data collected through a questionnaire. Although a survey questionnaire is a reliable data collection tool, data collected via the other tools such as think-aloud interviews and observations would be able to give more insight into students' writing strategy use. Second, the data was collected from only one Malaysian university, and the sample may not represent the whole university population in Malaysia. Therefore, replications of this research with different groups of ESL students from other universities are required to validate and confirm the main findings of this study. Thus, some caution is needed in generalizing the findings of this study to the full spectrum of Malaysian undergraduate students. These limitations need to be addressed in future research.

The findings of this study have some implications for language classroom and writing instruction. It is very essential for language teachers to convey to L2 learners that ESL writing is learnable and can be developed by employing appropriate strategies. Language teachers can promote the use of effective strategies by encouraging learners to share their own techniques and strategies in writing tasks. L2 learners should be encouraged to develop a repertoire of writing strategies in order to enhance their writing ability. Teachers should help students self-evaluate their writing tasks in order to become aware of their shortcomings and problems, and consequently think about the use of appropriate strategies. Furthermore, strategies can be taught explicitly by language instructors. L2 strategy instruction increases L2 learners' metacognitive awareness and their use of strategies which in turn will lead to improvements in their L2 writing ability. Given the important role academic writing plays within the educational contexts especially universities, writing teachers can use weblog or other online social networking sites to promote the use of different writing strategies among students by designing different writing activities which requires them to write their own opinion and communicate ideas.

\section{REFERENCES}

[1] Alhaisoni, E. (2012). A Think-aloud Protocols Investigation of Saudi English Major Students' Writing Revision Strategies in L1 (Arabic) and L2. English Language Teaching, 5(9) 144-155.

[2] Ansarimoghaddam, S., \& Tan, B. H. (2014). Undergraduates' Experiences and Attitudes of Writing in L1 and English. GEMA Online ${ }^{\circledR}$ Journal of Language Studies, 14(1) 7-28.

[3] Bandura, A. (1977). Self-efficacy: toward a unifying theory of behavioral change. Psychological review, 84(2), 191-215.

[4] Bidjerano, T., \& Dai, D. Y. (2007). The relationship between the big-five model of personality and self-regulated learning strategies. Learning and Individual Differences, 17(1), 69-81.

[5] Brown, H. D. (2000). Principles of language learning and teaching (4th ed.). White Plains, NY: Addison Wesley Longman. 
[6] Bruen, J. (2001). Strategies for success: Profiling the effective learner of German. Foreign Language Annals, 34(3), 216-225.

[7] Canagarajah, A. S. (2002). Critical academic writing and multilingual students: Ann Arbor: University of Michigan Press

[8] Chamot, A., \& El-Dinary, P. B. (1999). Children's learning strategies in language immersion classrooms. The Modern Language Journal, 83(3), 319-338.

[9] Chen, C. S. (2002). Self-regulated Learning Strategies and regulated Learning Strategies and Achievement in an Introduction to Information Systems Course. Information technology, learning, and performance journal, 20(1), 11-25.

[10] Cohen, A. D. (1998). Strategies in learning and using a second language: New York, NY: Longman.

[11] Dörnyei, Z. (2005). The psychology of the language learner: Individual Differences in second language acquisition: Mahwah, NJ: Lawrence Erlbaum.

[12] Graham, S., \& Perin, D. (2007). Effective strategies to improve writing of adolescents in middle and high schools. A report to Carnegie corporation of New York, New York: Alliance for Excellent Education.

[13] Green, J. M., \& Oxford, R. (1995). A closer look at learning strategies, L2 proficiency, and gender. TESOL quarterly, 29(2), 261-297.

[14] He, T.-h. (2005). Effects of mastery and performance goals on the composition strategy use of adult EFL writers. Canadian Modern Language Review/La Revue canadienne des langues vivantes, 61(3), 407-431.

[15] Hong-Nam, K., \& Leavell, A. G. (2006). Language learning strategy use of ESL students in an intensive English learning context. System, 34(3), 399-415.

[16] Khaldieh, S. A. (2000). Learning Strategies and Writing Processes of Proficient vs. Less - Proficient1 Learners of Arabic. Foreign Language Annals, 33(5), 522-533.

[17] Khalil, A. (2005). Assessment of language learning strategies used by Palestinian EFL learners. Foreign Language Annals, $38(1), 108-117$

[18] Komarraju, M., \& Nadler, D. (2013). Self-efficacy and academic achievement: Why do implicit beliefs, goals, and effort regulation matter? Learning and Individual Differences, 25, 67-72.

[19] Lai, Y. C. (2009). Language learning strategy use and English proficiency of university freshmen in Taiwan. TESOL quarterly, 43(2), 255-280.

[20] Leki, I. (1995). Coping strategies of ESL students in writing tasks across the curriculum. TESOL quarterly, 29(2), 235-260.

[21] Liu, H.-J. (2008). A Study Of The Interrelationship Between Listening Strategy Use, Listening Proficiency Levels, And Learning Style. Annual Review of Education, Communication \& Language Sciences, 5, 84-104.

[22] Liyanage, I., \& Bartlett, B. (2013). Personality types and languages learning strategies: Chameleons changing colours. System, 41(3), 598-608

[23] Ma, R., \& Oxford, R. L. (2014). A diary study focusing on listening and speaking: The evolving interaction of learning styles and learning strategies in a motivated, advanced ESL learner. System, 43, 101-113.

[24] Mu, C. (2005). A taxonomy of ESL writing strategies. In Redesigning Pedagogy: Research, Policy, Practice, May 30-June 1 2005(pp.1-10). Singapore.

[25] Nguyen, L. T. C., \& Gu, Y. (2013). Strategy-based instruction: A learner-focused approach to developing learner autonomy. Language Teaching Research, 17(1), 9-30.

[26] O'malley, J. M., \& Chamot, A. U. (1990). Learning strategies in second language acquisition. Cambridge: Cambridge University Press.

[27] O'Malley, J. M., Chamot, A. U., Stewner-Manzanares, G., Kupper, L., \& Russo, R. P. (1985). Learning strategies used by beginning and intermediate ESL students. Language Learning, 35(1), 21-46.

[28] Oxford, R. L. (1990). Language learning strategies: What every teacher should know.: Newbury House, Harper and Row, New York.

[29] Oxford, R. L. (2011). Teaching and researching language learning strategies.: Essex, UK: Pearson Longman.

[30] Park, G. P. (1997). Language learning strategies and English proficiency in Korean university students. Foreign Language Annals, 30(2), 211-221.

[31] Peacock, M., \& Ho, B. (2003). Student language learning strategies across eight disciplines. International Journal of Applied Linguistics, 13(2), 179-200.

[32] Petrić, B., \& Czárl, B. (2003). Validating a writing strategy questionnaire. System, 31(2), 187-215.

[33] Phillips, V. (1991). A look at learner strategy use and ESL proficiency. CATESOL Journal, (Nov), 57 - 67.

[34] Pintrich, P. R., Smith, D. A., García, T., \& McKeachie, W. J. (1993). Reliability and predictive validity of the Motivated Strategies for Learning Questionnaire (MSLQ). Educational and psychological measurement, 53(3), 801-813.

[35] Rao, Z. (2007). Training in brainstorming and developing writing skills. ELT journal, 61(2), 100-106.

[36] Rees-Miller, J. (1993). A critical appraisal of learner training: Theoretical bases and teaching implications. TESOL quarterly, 27(4), 679-689.

[37] Roca de Larios, J., Manchón, R., Murphy, L., \& Marín, J. (2008). The foreign language writer's strategic behaviour in the allocation of time to writing processes. Journal of Second Language Writing, 17(1), 30-47.

[38] Rubin, J. (1975). What the" good language learner" can teach us. TESOL quarterly, 9(1), 41-51.

[39] Salahshour, F., Sharifi, M., \& Salahshour, N. (2013). The relationship between language learning strategy use, language proficiency level and learner gender. Procedia-Social and Behavioral Sciences, 70, 634-643.

[40] Sasaki, M. (2000). Toward an empirical model of EFL writing processes: An exploratory study. Journal of Second Language Writing, 9(3), 259-291.

[41] Sasaki, M. (2002). Building an empirically-based model of EFL learners' writing processes S. Ransdell \& M.-L. Barbier (Eds.), New directions for research in L2 writing (pp. 49-80): Amsterdam: Kluwer Academic.

[42] Sasaki, M. (2007). Effects of Study - Abroad Experiences on EFL Writers: A Multiple-Data Analysis. The Modern Language Journal, 91(4), 602-620.

[43] Tolchinsky, L. (2006). The emergence of writing. In C. A. MacArthur, S. Graham, \& J. Fitzgerald (Eds.), Handbook of writing research (pp. 83-95). NY: Guilford. 
[44] Van Nuland, H. J., Dusseldorp, E., Martens, R. L., \& Boekaerts, M. (2010). Exploring the motivation jungle: Predicting performance on a novel task by investigating constructs from different motivation perspectives in tandem. International Journal of Psychology, 45(4), 250-259.

[45] Weigle, S. C. (2005). Second language writing expertise. In K. Johnson (Ed.), Expertise in second language learning and teaching (pp. 128-149). Basingstoke, New York, NY: Palgrave Macmillan.

[46] Wenden, A., \& Rubin, J. (1987). Learner Strategies in Language Learning: Englewood Cliffs, NY: Prentice Hall International.

[47] Whalen, K., \& Menard, N. (1995). L1 and L2 Writers' Strategic and Linguistic Knowledge: A Model of Multiple - Level Discourse Processing. Language Learning, 45(3), 381-418.

[48] Wharton, G. (2000). Language learning strategy use of bilingual foreign language learners in Singapore. Language Learning, $50(2), 203-243$.

[49] Wong, A. T. (2005). Writers' mental representations of the intended audience and of the rhetorical purpose for writing and the strategies that they employed when they composed. System, 33(1), 29-47.

Saeid Raoofi is currently a senior lecturer of English language education at Farhanginan University (Shahid Modares Campus), Iran. He received his PhD in Teaching of English as a Second Language (TESL) from the Universiti Putra Malaysia (UPM). He has published a number of articles in international peer-reviewed journals, and has presented several papers in international conferences. His research interests and expertise include SLA, testing and assessment, academic writing, and research methodology.

Massoud Binandeh teaches undergraduate students in elementary teacher education at the Farhanginan University (Shahid Modares Campus), Iran. He holds a PhD in Sociology from the Islamic Azad University (Science and Research Branch, Tehran), Iran. He has authored or co-authored a number of publications.

Saifullah Rahmani obtained his PhD in Educational Psychology from the University of Shahid Chamran, Iran. He is currently teaching at the Department of Education at Frhanigian Uinversity (Shahid Modares Campus) Iran. He has published several papers in international journals on various aspects of education. 